\title{
The Influence of Form and Rate on the Efficacy of Matrix-Based Fertilizers to Reduce Nutrient Leaching
}

\author{
James A. Entry and R. E. Sojka \\ USDA Agricultural Research Service, Northwest Irrigation and Soils Research Laboratory, 3793 North 3600 East, \\ Kimberly, ID 83443, USA \\ Correspondence should be addressed to James A. Entry, james_entry@nps.gov
}

Received 5 March 2009; Accepted 11 September 2009

Recommended by Amaresh K. Nayak

\begin{abstract}
We tested the efficacy of matrix-based fertilizers (MBFs) to reduce $\mathrm{NO}_{3}, \mathrm{NH}_{4}$, and total phosphorus (TP) leaching compared to Osmocote 14-14-14, a commercial slow release fertilizer (SRF) in greenhouse column studies. The MBFs covered a range of inorganic $\mathrm{N}$ and $\mathrm{P}$ in compounds that are relatively loosely bound (MBF4) and more tightly bound compounds (MBF5) with $\mathrm{Al}_{2}\left(\mathrm{SO}_{4}\right)_{3} \cdot 18 \mathrm{H}_{2} \mathrm{O}$ and/or $\mathrm{Fe}_{2}\left(\mathrm{SO}_{4}\right)_{3} \cdot 3 \mathrm{H}_{2} \mathrm{O}$ and with high ionic exchange compounds starch, chitosan, and lignin. When $\mathrm{N}$ and $\mathrm{P}$ are released, the chemicals containing these nutrients in the $\mathrm{MBF}$ bind $\mathrm{N}$ and $\mathrm{P}$ to an $\mathrm{Al}_{2}\left(\mathrm{SO}_{4}\right)_{3} \cdot 18 \mathrm{H}_{2} \mathrm{O}$ and $/ \mathrm{or} \mathrm{Fe}_{2}\left(\mathrm{SO}_{4}\right)_{3} \cdot 3 \mathrm{H}_{2} \mathrm{O}$ starch- chitosan- lignin matrix. SRF leachate contained a greater amount of $\mathrm{NO}_{3}, \mathrm{NH}_{4}$, DRP, and TP than leachate from MBF4 and MBF5 regardless of whether fertilizers were pellets, banded or broadcast, or fertilizer rate. St Augustine grass growing in soils receiving MBF4 and MBF5 had decreased shoot biomass by $49 \%$ to $56 \%$ and decreased total biomass by $33 \%$ to $46 \%$ respectively as grass receiving SRF. Although further greenhouse and field testing are necessary, results of this initial investigation are promising and with further development, testing, and rate calibration should be competitive with commercial fertilizers in environmentally sensitive markets.
\end{abstract}

Copyright ( $\odot 2009$ J. A. Entry and R. E. Sojka. This is an open access article distributed under the Creative Commons Attribution License, which permits unrestricted use, distribution, and reproduction in any medium, provided the original work is properly cited.

\section{Introduction}

Transport of $\mathrm{N}$ and $\mathrm{P}$ from agricultural soils to surface waters has been linked to eutrophication in fresh water and estuaries [1-3]. Eutrophication is widespread and rapidly expanding in fresh surface waters and coastal seas of the developed world. Eutrophication accounts for about $50 \%$ of the impaired lake area and $60 \%$ of the impaired rivers in the United States. It is also the most widespread pollution problem in estuaries [4]. In most lakes, streams, and coastal ecosystems, $\mathrm{N}$ is the element most limiting to production of plant material such as algae. Algal blooms cloud the water and block sunlight, causing native underwater flora to die contributing to a wide range of aquatic problems including summer fish kills, foul odors, and unpalatable tastes in drinking water [5]. Native underwater flora provide food, shelter, and spawning and nursery habitat for aquatic fauna. When algae die and decompose, oxygen is depleted, suffocating aquatic fauna. Phosphorus is also an essential element that contributes to both freshwater and coastal eutrophication. The incidence of harmful algal blooms in lakes, streams, and coastal oceans has dramatically increased in recent years [4]. This increase is linked to eutrophication and other factors, such as changes in aquatic food webs that may increase decomposition and nutrient recycling or reduce populations of algae-grazing fish. Increasing conversion of native lands to agriculture or development has increased the land area receiving fertilizer and contributes to $\mathrm{N}$ and $\mathrm{P}$ pollution of surface waters.

Fertilizer regimens could greatly benefit from more effective time release technologies that help managers better protect surface and ground water. We developed matrixbased fertilizers (MBFs) that may reduce $\mathrm{NH}_{4}, \mathrm{NO}_{3}$, dissolved reactive phosphate (DRP), and total $\mathrm{P}$ (TP) leaching. The MBFs (patent pending) cover a range of inorganic $\mathrm{N}$ and $\mathrm{P}$ in compounds that are relatively loosely bound (MBF4) to more tightly bound compounds (MBF5) mixed with $\mathrm{Al}_{2}\left(\mathrm{SO}_{4}\right)_{3} \cdot 18 \mathrm{H}_{2} \mathrm{O}$ and/or $\mathrm{Fe}_{2}\left(\mathrm{SO}_{4}\right)_{3} \cdot 3 \mathrm{H}_{2} \mathrm{O}$ and with 


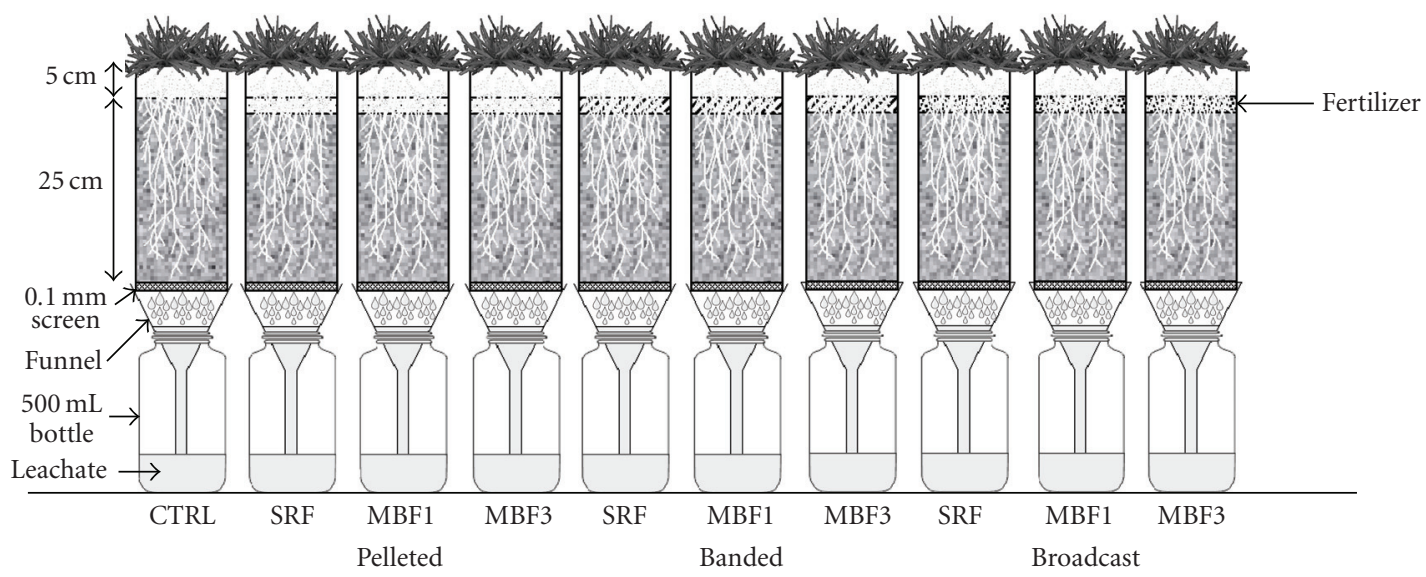

FIGURE 1: Diagram of column apparatus for fertilizer form.

the high ionic exchange compounds, starch, chitosan, and lignin. Starch, chitosan, and lignin were chosen because of their high concentration of ionic exchange sites and their decomposition characteristics. The organic components in the matrix degrade starch $>$ chitosan $>$ lignin in the order of more to less rapid. The matrix-based formulations can be made to bind inorganic nutrients relatively loosely (MBF4) to more tightly (MBF5) by increasing the concentration of $\mathrm{Al}_{2}\left(\mathrm{SO}_{4}\right)_{3} \cdot 18 \mathrm{H}_{2} \mathrm{O}$ and/or $\mathrm{Fe}_{2}\left(\mathrm{SO}_{4}\right)_{3} \cdot 3 \mathrm{H}_{2} \mathrm{O}$ and by varying the amounts of starch, chitosan, and lignin in the matrix. When the matrix is applied to soil, microorganisms degrade the starch in the matrix comparatively rapidly while chitosan degrades less rapidly. Lignin degrades the slowest and should retain most of its ionic exchange sites for a longer time in most soil environments. Nutrients bound to the $\mathrm{Al}_{2}\left(\mathrm{SO}_{4}\right)_{3} \cdot 18 \mathrm{H}_{2} \mathrm{O}$ and/or $\mathrm{Fe}_{2}\left(\mathrm{SO}_{4}\right)_{3} \cdot 3 \mathrm{H}_{2} \mathrm{O}$-starch-chitosanlignin matrix also become slowly available to plants as the organic components in the matrix degrade. The MBFs also cover a range of $\mathrm{N}$ and $\mathrm{P}$ concentration MBFs 1 and 4 contain a higher $\mathrm{N}$ and a high $\mathrm{P}$ concentration, MBF2 contains a more moderate $\mathrm{N}$ and a higher $\mathrm{P}$ concentration, and MBFs 3 and 5 contain a low $\mathrm{N}$ and a high $\mathrm{P}$ concentration $[6,7]$.

In previous experiments, Osmocote 14-14-14, a slow release fertilizer (SRF), combined with $\mathrm{Al}_{2}\left(\mathrm{SO}_{4}\right)_{3} \cdot 18 \mathrm{H}_{2} \mathrm{O}$ and $\mathrm{Fe}_{2}\left(\mathrm{SO}_{4}\right)_{3} \cdot 3 \mathrm{H}_{2} \mathrm{O}$ leached $78 \%-84 \%$ more $\mathrm{NH}_{4}, 58-78 \%$ more TP, $20-30 \%$ more TRP, and $61 \%-77 \%$ more DRP than MBF formulations [6]. The SRF treatment leached 34\% less $\mathrm{NO}_{3}$ than MBF formulations. Total plant weight did not differ among fertilizer treatments. Arbuscular mycorrhizal infection did not differ among plants receiving SRF and MBF formulations. Entry and Sojka [7] found that in three soil textures the SRF leachate contained a higher amount of $\mathrm{NH}_{4}$, $\mathrm{NO}_{3}$, and TP than leachate from MBF formulations. However, wheat plants growing in soils receiving SRF had greater shoot, root, and total biomass than all MBF formulations. Arbuscular mycorrhizal infection in plant roots did not differ among plants growing in soil receiving SRF, MBFs, and non amended control treatments. In this study our objectives were to determine the influence of (1) MBF application method of pellet, banded, or broadcast on plant growth and
$\mathrm{N}$ and P leaching and (2) MBF4 and MBF5 and the slow release fertilizer (SRF) Osmocote 14-14-14 at low, moderate, or high fertilizer application rates on plant growth and $\mathrm{N}$ and $\mathrm{P}$ leaching in two separates soil types.

\section{Materials and Methods}

\subsection{Fertilizer Treatments}

2.1.1. Experiment 1: Fertilizer Form. Treatment 1 was a control and no fertilizer was applied (Figure 1). Treatments 2,5 , and 8 were $5.0 \mathrm{~g}$ of the Osmocote (14-14-14) slow release fertilizer (SRF) which was equal to $0.210 \mathrm{~m} \mathrm{~N}, 0.200 \mathrm{gP}$, and $0.180 \mathrm{~g} \mathrm{~K}$ per column, and was equal to $267 \mathrm{~kg} \mathrm{~N}^{-1}$, $255 \mathrm{~kg} \mathrm{Pha}^{-1}$, and $159 \mathrm{~kg} \mathrm{Kha}^{-1}$ (Table 1). Treatments 3, 6, and 9 were MBF4 which received $0.191 \mathrm{~g} \mathrm{~N}$ and $0.206 \mathrm{P}$ per column and was equal to $243 \mathrm{~kg} \mathrm{~N}^{-1}$ and $262 \mathrm{~kg} \mathrm{P} \mathrm{ha}^{-1}$. Treatments 4,7 , and 10 were MBF5 which received $0.86 \mathrm{~g} \mathrm{~N}$ and $0.185 \mathrm{~g} \mathrm{P}$ per column and was equal to $121 \mathrm{~kg} \mathrm{~N} \mathrm{ha}^{-1}$ and $287 \mathrm{~kg} \mathrm{Pha}^{-1}$. Fertilizer treatments 2,3 , and 4 were applied as $1 \mathrm{~cm}$ diameter pellets equally distributed in the top $4 \mathrm{~cm}$ of each column. Fertilizers in treatments 4, 5, and 6 were banded and were applied as $2 \mathrm{~cm}$ diameter bands $4 \mathrm{~cm}$ long in the top $4 \mathrm{~cm}$ in each column. Fertilizers in treatments 8 , 9 , and 10 were broadcast and mixed with soils in the top $4 \mathrm{~cm}$ in each column. We then added 8000 spores of Glomus interadicies in $1.00 \mathrm{~mL}$ of reverse osmosis water to all $\mathrm{MBF}$ treatments (per column) to increase plant nutrient uptake.

2.1.2. Experiment 2: Fertilizer Rate. Treatment 1 was a control; no fertilizer was applied to the columns (Figure 2). Fertilizer treatments 2, 3, and 4 were applied at a low rate and broadcast applied as described above in the fertilizer form experiment and mixed with the top $4 \mathrm{~cm}$ of soil. Treatment 5 was $10.0 \mathrm{~g}$ of Osmocote (14-14-14) slow release fertilizer (SRF) which was equal to $0.420 \mathrm{~g} \mathrm{~N}$ and $0.400 \mathrm{gP}$ per column, which was equal to $534 \mathrm{~kg} \mathrm{Nha}^{-1}$ and $510 \mathrm{~kg} \mathrm{Pha}^{-1}$ (Table 2). Treatment 6 was MBF4 which received $0.382 \mathrm{~g} \mathrm{~N}$ and $0.412 \mathrm{gP}$ per column and was equal to $486 \mathrm{~kg} \mathrm{Nha}^{-1}$ and $510 \mathrm{~kg} \mathrm{Pha}^{-1}$. Treatment 7 was MBF5 


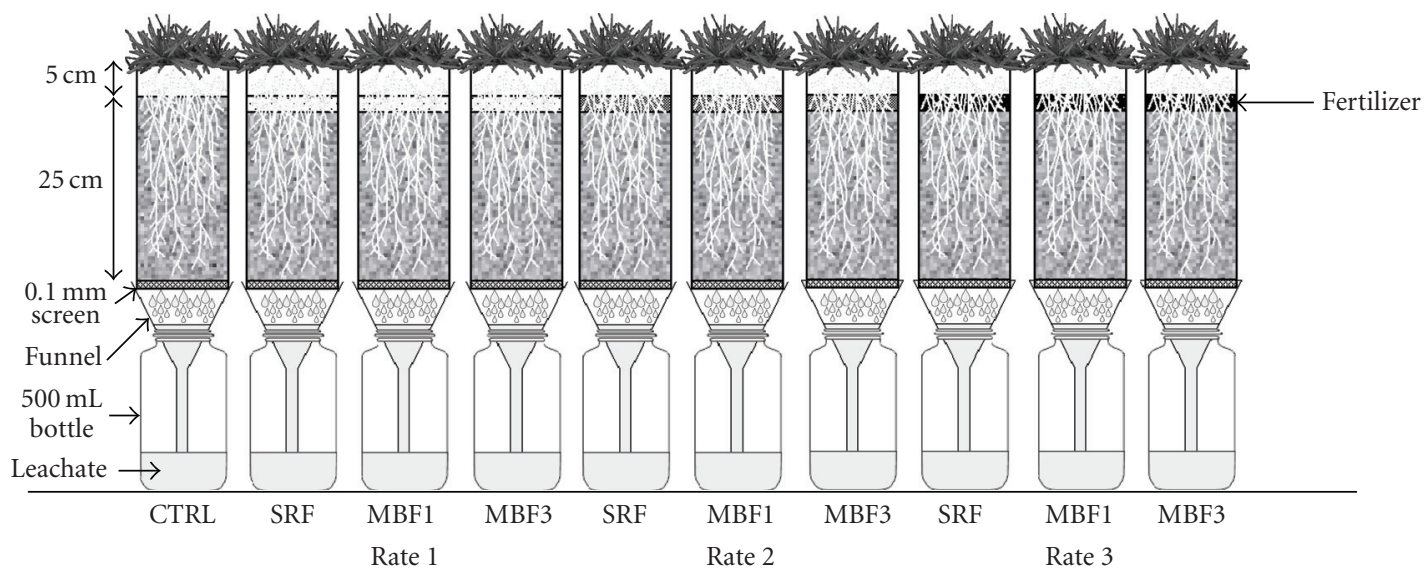

FIgURE 2: Diagram of column apparatus for fertilizer rate.

TABLE 1: Chemical compounds used to comprise three different matrix-based fertilizers in experiment 1 fertilizer form ${ }^{(a)}$.

\begin{tabular}{|c|c|c|c|c|c|c|c|c|c|c|}
\hline Treatment & 1 & 2 & 3 & 4 & 5 & 6 & 7 & 8 & 9 & 10 \\
\hline Compound & CONT & SRF & MBF4 & MBF5 & SRF & MBF4 & MBF5 & SRF & MBF4 & MBF5 \\
\hline \multirow[t]{2}{*}{ Fertilizer Form } & & & Banded & & & Broadcas & & & Pellet & \\
\hline & \multicolumn{10}{|c|}{ g compound in each column } \\
\hline $\mathrm{NH}_{4} \mathrm{NO}_{3}$ & 0.000 & 0.210 & 0.000 & 0.000 & 0.126 & 0.000 & 0.000 & 0.126 & 0.000 & 0.000 \\
\hline $\mathrm{P}_{2} \mathrm{O}_{5}$ & 0.000 & 0.200 & 0.000 & 0.000 & 0.120 & 0.000 & 0.000 & 0.120 & 0.000 & 0.000 \\
\hline $\mathrm{K}_{2} \mathrm{O}$ & 0.000 & 0.180 & 0.180 & 0.180 & 0.108 & 0.180 & 0.180 & 0.108 & 0.180 & 0.180 \\
\hline $\mathrm{Ca}\left(\mathrm{NO}_{3}\right)_{2} 4 \mathrm{H}_{2} \mathrm{O}$ & 0.000 & 0.000 & 0.472 & 0.236 & 0.000 & 0.472 & 0.236 & 0.000 & 0.472 & 0.236 \\
\hline $\mathrm{Al}\left(\mathrm{NO}_{3}\right)_{3} 9 \mathrm{H}_{2} \mathrm{O}$ & 0.000 & 0.000 & 0.750 & 0.000 & 0.000 & 0.750 & 0.000 & 0.000 & 0.750 & 0.000 \\
\hline $\mathrm{NH}_{4}\left(\mathrm{H}_{2} \mathrm{PO}_{4}\right)$ & 0.000 & 0.000 & 0.230 & 0.115 & 0.000 & 0.230 & 0.115 & 0.000 & 0.230 & 0.115 \\
\hline $\mathrm{Ca}\left(\mathrm{H}_{2} \mathrm{PO}_{4}\right)_{2}$ & 0.000 & 0.000 & 0.468 & 0.234 & 0.000 & 0.468 & 0.234 & 0.000 & 0.468 & 0.234 \\
\hline $\mathrm{Fe}\left(\mathrm{P}_{2} \mathrm{O}_{7}\right)$ & 0.000 & 0.000 & 0.334 & 0.750 & 0.000 & 0.334 & 0.750 & 0.000 & 0.334 & 0.750 \\
\hline $\mathrm{Al}_{2}\left(\mathrm{PO}_{4}\right)_{3}$ & 0.000 & 0.000 & 0.360 & 0.000 & 0.000 & 0.360 & 0.000 & 0.000 & 0.360 & 0.000 \\
\hline $\mathrm{Al}_{2}\left(\mathrm{SO}_{4}\right)_{3} 18 \mathrm{H}_{2} \mathrm{O}$ & 0.000 & 0.000 & 0.366 & 0.000 & 0.000 & 0.366 & 0.000 & 0.000 & 0.366 & 0.000 \\
\hline $\mathrm{Fe}_{2}\left(\mathrm{SO}_{4}\right)_{3} 3 \mathrm{H}_{2} \mathrm{O}$ & 0.000 & 0.000 & 0.800 & 1.600 & 0.000 & 0.800 & 1.600 & 0.000 & 0.800 & 1.600 \\
\hline Starch & 0.000 & 0.000 & 1.000 & 1.000 & 0.000 & 1.000 & 1.000 & 0.000 & 1.000 & 1.000 \\
\hline Chitosan & 0.000 & 0.000 & 1.000 & 1.000 & 0.000 & 1.000 & 1.000 & 0.000 & 1.000 & 1.000 \\
\hline Lignin & 0.000 & 0.000 & 1.000 & 1.000 & 0.000 & 1.000 & 1.000 & 0.000 & 1.000 & 1.000 \\
\hline
\end{tabular}

(a) MBF4 is matrix-based fertilizer formulation $1=243 \mathrm{~kg} \mathrm{Nha}^{-1}$ and $262 \mathrm{~kg} \mathrm{Pha}^{-1}$; MBF5 is matrix-based fertilizer formulation $3=121 \mathrm{~kg} \mathrm{~N}^{-1}$ and $236 \mathrm{~kg} \mathrm{Pha}^{-1}$. SRF is the slow release fertilizer $5.0 \mathrm{~g}$ of Osmocote (14-14-14) $=267 \mathrm{~kg} \mathrm{Nha}^{-1}, 255 \mathrm{~kg} \mathrm{P} \mathrm{ha}^{-1}$, and $159 \mathrm{~kg} \mathrm{~K} \mathrm{ha}^{-1}$.

which received $0.172 \mathrm{~g} \mathrm{~N}$ and $0.370 \mathrm{gP}$ per column and was equal to $242 \mathrm{~kg} \mathrm{Nha}^{-1}$ and $472 \mathrm{~kg} \mathrm{Pha}^{-1}$. Treatment 8 was $15.0 \mathrm{~g}$ of Osmocote (14-14-14) slow release fertilizer (SRF) which was equal to $0.630 \mathrm{~g} \mathrm{~N}$ and $0.600 \mathrm{~g} \mathrm{P}$ per column and $801 \mathrm{~kg} \mathrm{Nha}^{-1}$ and $765 \mathrm{~kg} \mathrm{Pha}^{-1}$. Treatment 9 was MBF4 which received $0.573 \mathrm{~g} \mathrm{~N}$ and $0.618 \mathrm{gP}$ per column and was equal to $729 \mathrm{~kg} \mathrm{Nha}^{-1}$ and $786 \mathrm{~kg} \mathrm{Pha}^{-1}$. Treatment 10 was MBF5 which received $0.258 \mathrm{~g} \mathrm{~N}$ and $555 \mathrm{~g} P$ per column and was equal to $258 \mathrm{~kg} \mathrm{Nha}^{-1}$ and $708 \mathrm{~kg} \mathrm{Pha}^{-1}$. Fertilizers in all treatments were broadcast and mixed with soils in the top $4 \mathrm{~cm}$ in each column.

2.2. Column Description. A $2.0 \mathrm{~mm}$ wire screen was cut into squares $(125 \times 125 \mathrm{~mm})$ and secured to the bottom of each $10.0 \mathrm{~cm}$ diameter $\times 30 \mathrm{~cm}$ long polyvinyl chloride cylinder. A
$14 \mathrm{~cm}$ diameter funnel was placed below each column in the rack and secured. Three kilograms of soil were placed in each column (columns were filled to $25 \mathrm{~cm}$ ) leaving a $5 \mathrm{~cm}$ space at the top of each column. Soil in columns was loosely packed and then repeatedly washed with reverse osmosis water to flush nutrients that could be loosely held to soil particles. Columns were allowed to drain for 1 hour prior to the start of leachate collection as described below.

2.3. Soil Descriptions. Two different textured soils were used to determine the effectiveness of the fertilizers to reduce leaching. The Simco soil was a coarse-loamy sand and classified as a mixed nonacidic, mesic Xeric Torriorthent. The Kuna soil was a sandy loam and classified as a mixed, mesic lithic Xerollic Camborthid [8]. Soil physical and 
TABle 2: Chemical compounds used to comprise three different matrix-based fertilizers in experiment 2: fertilizer rate ${ }^{(a)}$.

\begin{tabular}{|c|c|c|c|c|c|c|c|c|c|c|}
\hline Treatment & 1 & 2 & 3 & 4 & 5 & 6 & 7 & 8 & 9 & 10 \\
\hline \multirow[t]{3}{*}{ Compound } & CONT & SRF & MBF4 & MBF5 & SRF & MBF4 & MBF5 & SRF & MBF4 & MBF5 \\
\hline & & & Low Rate & & \multicolumn{3}{|c|}{ Moderate Rate } & \multicolumn{3}{|c|}{ High Rate } \\
\hline & \multicolumn{10}{|c|}{ g compound in each column } \\
\hline $\mathrm{NH}_{4} \mathrm{NO}_{3}$ & 0.000 & 0.210 & 0.000 & 0.000 & 0.420 & 0.000 & 0.000 & 0.630 & 0.000 & 0.000 \\
\hline $\mathrm{P}_{2} \mathrm{O}_{5}$ & 0.000 & 0.200 & 0.000 & 0.000 & 0.400 & 0.000 & 0.000 & 0.600 & 0.000 & 0.000 \\
\hline $\mathrm{K}_{2} \mathrm{O}$ & 0.000 & 0.180 & 0.180 & 0.180 & 0.360 & 0.360 & 0.360 & 0.540 & 0.540 & 0.540 \\
\hline $\mathrm{Ca}\left(\mathrm{NO}_{3}\right)_{2} 4 \mathrm{H}_{2} \mathrm{O}$ & 0.000 & 0.000 & 0.472 & 0.236 & 0.000 & 0.944 & 0.472 & 0.000 & 1.888 & 0.944 \\
\hline $\mathrm{Al}\left(\mathrm{NO}_{3}\right)_{3} 9 \mathrm{H}_{2} \mathrm{O}$ & 0.000 & 0.000 & 0.750 & 0.000 & 0.000 & 1.500 & 0.000 & 0.000 & 3.000 & 0.000 \\
\hline $\mathrm{NH}_{4}\left(\mathrm{H}_{2} \mathrm{PO}_{4}\right)$ & 0.000 & 0.000 & 0.230 & 0.115 & 0.000 & 0.460 & 0.230 & 0.000 & 0.920 & 0.460 \\
\hline $\mathrm{Ca}\left(\mathrm{H}_{2} \mathrm{PO}_{4}\right)_{2}$ & 0.000 & 0.000 & 0.468 & 0.234 & 0.000 & 0.936 & 0.468 & 0.000 & 1.872 & 0.936 \\
\hline $\mathrm{Fe}\left(\mathrm{P}_{2} \mathrm{O}_{7}\right)$ & 0.000 & 0.000 & 0.334 & 1.490 & 0.000 & 0.668 & 2.980 & 0.000 & 1.336 & 5.960 \\
\hline $\mathrm{Al}_{2}\left(\mathrm{PO}_{4}\right)_{3}$ & 0.000 & 0.000 & 0.360 & 0.000 & 0.000 & 0.720 & 0.000 & 0.000 & 1.440 & 0.000 \\
\hline $\mathrm{Al}_{2}\left(\mathrm{SO}_{4}\right)_{3} 18 \mathrm{H}_{2} \mathrm{O}$ & 0.000 & 0.000 & 0.366 & 0.000 & 0.000 & 0.732 & 0.000 & 0.000 & 1.464 & 0.000 \\
\hline $\mathrm{Fe}_{2}\left(\mathrm{SO}_{4}\right)_{3} 3 \mathrm{H}_{2} \mathrm{O}$ & 0.000 & 0.000 & 0.800 & 1.600 & 0.000 & 1.600 & 3.200 & 0.000 & 3.200 & 6.400 \\
\hline Starch & 0.000 & 0.000 & 1.000 & 1.000 & 0.000 & 1.000 & 1.000 & 0.000 & 1.000 & 1.000 \\
\hline Chitosan & 0.000 & 0.000 & 1.000 & 1.000 & 0.000 & 1.000 & 1.000 & 0.000 & 1.000 & 1.000 \\
\hline Lignin & 0.000 & 0.000 & 1.000 & 1.000 & 0.000 & 1.000 & 1.000 & 0.000 & 1.000 & 1.000 \\
\hline
\end{tabular}

(a) At the low rate: MBF4 $=243 \mathrm{~kg} \mathrm{Nha}^{-1}$ and $262 \mathrm{~kg} \mathrm{Pha}^{-1}$; MBF5 $=121 \mathrm{~kg} \mathrm{Nha}^{-1}$ and $236 \mathrm{~kg} \mathrm{Pha}^{-1}$; SRF is the slow release fertilizer $5.0 \mathrm{~g}$ of Osmocote $(14-14-14)=267 \mathrm{~kg} \mathrm{Nha}^{-1}$ and $255 \mathrm{~kg} \mathrm{Pha}^{-1}$ and $159 \mathrm{~kg} \mathrm{~K} \mathrm{ha}^{-1}$. At the moderate rate: MBF4 $=486 \mathrm{~kg} \mathrm{Nha}^{-1}$ and $524 \mathrm{~kg} \mathrm{Pha}^{-1}$; MBF5 is $242 \mathrm{~kg} \mathrm{~N} \mathrm{ha}^{-1}$ and $472 \mathrm{~kg} \mathrm{Pha}^{-1}$; SRF is the slow release fertilizer $10.0 \mathrm{~g}$ of Osmocote $(14-14-14)=534 \mathrm{~kg} \mathrm{Nha}^{-1}$ and $510 \mathrm{~kg} \mathrm{P} \mathrm{ha}^{-1}$. At the high rate: MBF4 $=729 \mathrm{~kg} \mathrm{~N}^{-1}$ and $786 \mathrm{~kg} \mathrm{Pha}^{-1}$; MBF5 $=363 \mathrm{~kg} \mathrm{Nha}^{-1}$ and $708 \mathrm{~kg} \mathrm{Pha}^{-1}$; SRF is the slow release fertilizer $15 \mathrm{~g}$ of Osmocote $(14-14-14)=801 \mathrm{~kg} \mathrm{Nha}^{-1}, 765 \mathrm{~kg} \mathrm{Pha}^{-1}$, and $477 \mathrm{~kg} \mathrm{~K} \mathrm{ha}^{-1}$.

microbiological properties are presented in (Sojka et al., [9] and Entry et al., [10]).

2.4. Experimental Design. The fertilizer form experiment was arranged in a completely randomized design with 3 fertilizer treatments (SRF, MBF4, and MBF5) $\times 3$ forms of fertilizer application (pellet, banded, and broadcast) $\times 2$ soil textures (loam and loamy sand) $\times 3$ replications $\times 4$ leachate measurements at $21,42,63$, and 84 days. There were a total of 54 columns and 216 leachate measurements. The fertilizer rate experiment was also arranged in a completely randomized design with 3 fertilizer treatments (SRF, MBF4, and MBF5) $\times 3$ fertilizer rate treatments (low, moderate, and high) $\times 2$ soil textures (loam and loamy sand) $\times 3$ replications $\times 6$ leachate measurements at $21,42,63,84$, 105 , and 126 days. There were a total of 54 columns and 354 leachate measurements.

2.5. Fertilizer Placement and Growing Conditions. In experiments 1 and 2 we placed a $2 \mathrm{~cm} \times 2 \mathrm{~cm}$ starter patch (approximately $10 \mathrm{~g}$ ) of St Augustine grass (Stenotaphrum secundatum (Walt.) Kuntze) in the top $10 \mathrm{~cm}$ of each column. Plants were watered with $100 \mathrm{~mL}$ of water daily to maintain field capacity of the soil. Leachate did not flow through columns when $100 \mathrm{~mL}$ reverse osmosis water was applied. We collected leachate on the above stated days after fertilizer placement (start of the experiment) by giving Plants $500 \mathrm{~mL}$ reverse osmosis water on the above stated days in lieu of the $100 \mathrm{~mL}$ daily reverse osmosis water. On each sampling day approximately $200 \mathrm{~mL}$ leachate was collected from each column and prepared for analysis. Subsamples were analyzed for $\mathrm{NO}_{3}$ and $\mathrm{NH}_{4}, \mathrm{DRP}$, and $\mathrm{TP}$ as described below. Throughout the experiment plants were exposed to light having a photosynthetic active radiation of 400-700 : mol m${ }^{-2} \mathrm{~S}^{-1}$ and a 14-16-hour photoperiod.

2.6. Harvesting and Arbuscular Mycorrhizae Assessment. Plants were harvested after 84 days in experiment 1 and 126 days in experiment 2. At harvest plants were removed from the columns and separated into roots and shoots. Roots were washed in reverse osmosis water until all visible soil particles were removed. Three grams of roots were randomly selected from each plant and placed in a solution of $2.5 \%(\mathrm{w} / \mathrm{v})$ $\mathrm{KOH}$ for 24 hours. The roots in the $\mathrm{KOH}$ solution were then placed in an autoclave for 5 minutes and then rinsed in 2\% $\mathrm{HCl}$ for 24 hours. Roots were then placed in $0.05 \%(\mathrm{w} / \mathrm{v})$ trypan blue in acidic glycerol for 24 hours [11]. Roots were observed for hyphal colonization under a 200x microscope by the cross hair intersection method [12]. Approximately 100 intersections were scored and used to determine percent of root length infected. Root tissue excluding roots examined for mycorrhizal infection and shoot tissue was dried at 80EC for 48 hours and weighed for shoot and root biomass.

2.7. Chemical Analysis. Nitrate and $\mathrm{NH}_{4}$ were determined using a Lachat Automated Ion Analyzer (Quickchem 8000 Systems, Milwaukee, WI) using the method described by APHA [13]. Total P and DRP in leachate were determined by digesting $25 \mathrm{~mL}$ aliquots in an autoclave at $103.5 \mathrm{kPa}$ and 121EC for 60 minutes with $4.0 \mathrm{~mL}$ acidified ammonium 
TABLE 3: Total amount of $\mathrm{NH}_{4}, \mathrm{NO}_{3}$, total phosphorus (TP), and dissolved reactive phosphorus (DRP) leached from sandy loam and loam soils and shoot and root dry weight arbuscular mycorrhizal infection of St. Augustine grass receiving pellet, banded, or broadcast.

\begin{tabular}{|c|c|c|c|c|c|c|c|c|}
\hline Fertilizer & DRP & $\mathrm{TP}$ & $\mathrm{NO}_{3}$ & $\mathrm{NH}_{4}$ & Shoot Weight & Root Weight & Total weight & Mycorrhizal infection $_{\mathrm{d}}$ \\
\hline & \multicolumn{4}{|c|}{ mg element $\mathrm{L}^{-1}$ water } & \multicolumn{3}{|c|}{ g } & $\%$ \\
\hline Fertilizer not applied (Control) & $3.33^{(\mathrm{b})}$ & $5.47^{(\mathrm{b})}$ & $9.94^{(\mathrm{c})}$ & $0.10^{(\mathrm{c})}$ & $2.69^{(\mathrm{d})}$ & $0.98^{(\mathrm{d})}$ & $3.67^{(\mathrm{d})}$ & $44^{(\mathrm{a})}$ \\
\hline Matrix Based Fertilizer 1 (MBF4) & $4.68^{(\mathrm{b})}$ & $5.00^{(\mathrm{b})}$ & $12.57^{(\mathrm{b})}$ & $0.45^{(\mathrm{b})}$ & $14.21^{(\mathrm{b})}$ & $3.34^{(\mathrm{b})}$ & $17.58^{(\mathrm{b})}$ & $48^{(\mathrm{a})}$ \\
\hline Matrix Based Fertilizer 3 (MBF5) & $3.29^{(\mathrm{b})}$ & $3.89^{(\mathrm{b})}$ & $4.39^{(\mathrm{d})}$ & $0.28^{(\mathrm{b})}$ & $7.38^{(\mathrm{c})}$ & $1.88^{(\mathrm{c})}$ & $9.26^{(\mathrm{c})}$ & $39^{(\mathrm{a})}$ \\
\hline Osmocote 14-14-14 (SRF) & $10.78^{(a)}$ & $8.33^{(\mathrm{a})}$ & $108.29^{(\mathrm{a})}$ & $3.17^{(\mathrm{a})}$ & $30.68^{(a)}$ & $3.49^{(a)}$ & $36.24^{(\mathrm{a})}$ & $37^{(\mathrm{a})}$ \\
\hline
\end{tabular}

(a) In each column, values followed by the same letter are not significantly different as determined by the least square means test $(P \leq .05 ; n=36)$.

(b) Statistical comparisons of parameters in water are presented with regard to fertilizer because interactions of and soil $\times$ fertilizer $\times$ fertilizer form $\times$ week sampled, soil $\times$ fertilizer $\times$ fertilizer form, soil $\times$ fertilizer $\times$ week sampled were not significant in the GLM model $(P \leq .05 ; n=18)$.

(c) Fertilizer rates were MBF4 $=243 \mathrm{~kg} \mathrm{Nha}^{-1}$ and $262 \mathrm{~kg} \mathrm{Pha}^{-1} ; \mathrm{MBF} 5=121 \mathrm{~kg} \mathrm{~N} \mathrm{ha}^{-1}$ and $236 \mathrm{~kg} \mathrm{Pha}^{-1} ; \mathrm{SRF}=267 \mathrm{~kg} \mathrm{~N} \mathrm{ha}^{-1}, 255 \mathrm{~kg} \mathrm{P}^{-1}$.

(d) Percent (\%) of fine roots infected with arbuscular mycorrhizae.

persulfate [13]. Samples were dried at $65^{\circ} \mathrm{C}$ for 72 hours and passed through a $2 \mathrm{~mm}$ sieve. Total $\mathrm{N}$ was determined using standard microkjeldahl procedures modified for $\mathrm{NO}_{3}[14]$. A $2 \mathrm{~g}$ subsample of soil was extracted $10 \mathrm{~mL} 1 \mathrm{~N}$ ammonium acetate [15] and analyzed for $\mathrm{Mn}, \mathrm{Fe}, \mathrm{Al}, \mathrm{Si}, \mathrm{S}$, and $\mathrm{Zn}$ being determined using inductively coupled plasma emission spectrometry (ICP; Perkin-Elmer, Boston, MA). At harvest, plant root and shoot material were weighed then ground to pass a $1 \mathrm{~mm}$ mesh. A $0.50 \mathrm{~g}$ subsample was analyzed for total $\mathrm{N}$ with a LECO CHN-600 nitrogen analyzer (St. Joseph, Michigan). A $0.25 \mathrm{~g}$ subsample was ashed at 500EC, dissolved in $25 \mathrm{~mL}$ of $1.0 \mathrm{M} \mathrm{HCl}$, brought to $50 \mathrm{~mL}$ volume with reverse osmosis water, and analyzed for $\mathrm{P}, \mathrm{K}, \mathrm{Ca}, \mathrm{Mg}$, $\mathrm{Mn}, \mathrm{Fe}, \mathrm{Cu}, \mathrm{B}$, and $\mathrm{Zn}$ using an ICP.

2.8. Statistical Analysis. All data sets were tested for normal distribution with Statistical Analysis Systems [16] and then analyzed using general linear models (GLMs) procedures for a completely random design. In all analyses, residuals were equally distributed with constant variances. Differences reported throughout are significant at $P \leq .05$, as determined by the Least Squares Means test. Correlations were determined using DRP, TP, $\mathrm{NH}_{4}$, and $\mathrm{NO}_{3}$ as the independent $(x)$ variable and days since fertilizers were applied as dependant $(y)$ variables using SAS programs. Regression slopes and $y$ intercepts among fertilizers were compared using $t$ ratios [16]. Regression slopes and $y$ intercepts among fertilizers were also compared using confidence limits. Assume that a variance ratio of 1 and confidence limits of the slope and each intercept were calculated at $P \leq .05$. Confidence limits of the $y$ intercepts were estimated by confidence limits of the slope and mean values of the $x$ and $y$ variables. If the confidence interval region includes the matched pairs mean difference of 0 on the $y$-axis, then the results obtained by each method are not significantly different at $P \leq .05[17,18]$.

\section{Results}

3.1. Fertilizer Form. The GLM models of leached nutrients for fertilizer type $\times$ fertilizer form $\times$ soil type $\times$ sample day, fertilizer $x$ fertilizer form, soil type $x$ fertilizers form, soil type $\times$ fertilizers, and soil type $\times$ sample day were not significant. Therefore, statistical comparisons of $\mathrm{NO}_{3}, \mathrm{NH}_{4}, \mathrm{DRP}, \mathrm{TP}$, shoot, root, and total plant weight and shoot and root nutrient concentrations are presented for fertilizer treatments because GLM models showed that these interactions were significant at $P \leq .05[17,18]$. plants growing in soils receiving SRF had greater shoot, root, and total biomass than all fertilizer formulations; MBF4 and MBF5 decreased shoot biomass by $53 \%$ and $76 \%$, decreased root biomass by $4 \%$ and $46 \%$ and total plant biomass by $51 \%$ and $74 \%$ compared to the SRF (Table 3). Arbuscular mycorrhazal infection in plant roots did not consistently differ among plants growing in soil receiving SRF and all MBF formulations and plants growing in soils receiving no fertilizer (control). We found that at from $45 \%$ to $58 \%$ of the $\mathrm{NH}_{4}, 40 \%$ to $85 \%$ of the $\mathrm{NO}_{3}, 49$ to $86 \%$ of the DRP and 33 to $83 \%$ of the TP was leached from soil columns in the first 63 days after Osmocote (14-14-14) SRF was applied (data not shown). After 84 days, SRF leachate contained a greater amount of $\mathrm{NO}_{3}, \mathrm{NH}_{4}, \mathrm{DRP}$, and TP than leachate from MBF4 and MBF5 regardless of fertilizer application form (Table 3). MBF4 and MBF5 reduced DRP in leachate by $57 \%$ and $70 \%$, respectively, compared to the SRF. MBF4 and MBF5 reduced TP in leachate by $40 \%$ and $53 \%$, respectively, compared to the SRF. MBF4 and MBF5 reduced $\mathrm{NO}_{3}$ in leachate by $86 \%$ and $91 \%$ respectively, compared to the SRF. MBF4 and MBF5 reduced $\mathrm{NH}_{4}$ in leachate by $88 \%$ and $96 \%$, respectively, compared to the SRF. The concentration of N, $\mathrm{P}, \mathrm{K}, \mathrm{Mg}, \mathrm{Mn}, \mathrm{Fe}, \mathrm{Zn}, \mathrm{Al}$, and $\mathrm{Na}$ shoot tissue did not differ among fertilizer or form of application treatments (data not shown). Nitrogen concentration was higher in root tissue of plants receiving the SRF than MBF5, regardless of the form of fertilizer application (data not shown). The concentration of Fe was higher in root tissue of plants receiving the control and MBF5 than SRF or MBF4.

3.2. Fertilizer Rate. The GLM models of leached nutrients for fertilizer type $\times$ fertilizer rate $\times$ soil type $\times$ sample day, soil type $\times$ fertilizers rate, soil type $\times$ fertilizers, and soil type $\times$ sample day were not significant. Therefore, statistical comparisons of DRP, TP $\mathrm{NO}_{3}, \mathrm{NH}_{4}$, shoot, root, and total plant weight and shoot and root nutrient concentrations are presented for fertilizer $\times$ fertilizer rate 
TABLE 4: Total amount of $\mathrm{NH}_{4}, \mathrm{NO}_{3}$, total phosphorus (TP), and dissolved reactive* phosphorus (DRP) leached from sandy loam and loam soils and shoot and root dry weight and arbuscular mycorrhizal infection of St. Augustine grass receiving low, moderate, and high rate of matrix-based fertilizer 1 (MBF4), matrix-based fertilizer 3 (MBF5), and the slow release fertilizer Osmocote (14-14-14) (SRF) over 126 days.

\begin{tabular}{|c|c|c|c|c|c|c|c|c|c|c|c|}
\hline Fertilizer & Rate & $\begin{array}{l}\text { Nitrogen } \\
\text { Applied }\end{array}$ & $\begin{array}{c}\text { Phosphorus } \\
\text { Applied }\end{array}$ & DRP & $\mathrm{TP}$ & $\mathrm{NO}_{3}$ & $\mathrm{NH}_{4}$ & $\begin{array}{l}\text { Shoot } \\
\text { Weight }\end{array}$ & $\begin{array}{c}\text { Root } \\
\text { Weight }\end{array}$ & $\begin{array}{c}\text { Total } \\
\text { Weight }\end{array}$ & Myc \\
\hline & & \multicolumn{2}{|c|}{$\mathrm{kg} \mathrm{ha}^{-1}$} & \multicolumn{4}{|c|}{ mg element $\mathrm{L}^{-1}$ water } & & $\mathrm{g}$ & & $\%$ \\
\hline $\begin{array}{l}\text { Fertilizer not } \\
\text { applied } \\
\text { (Control) }\end{array}$ & & 0 & 0 & $3.86^{(\mathrm{e})}$ & $7.16^{(\mathrm{d})}$ & $8.45^{(\mathrm{f})}$ & $0.83^{(\mathrm{e})}$ & $21.82^{(\mathrm{d})}$ & $16.35^{(\mathrm{b})}$ & $38.18^{(\mathrm{e})}$ & $70^{(\mathrm{a})}$ \\
\hline $\begin{array}{l}\text { Matrix Based } \\
\text { Fertilizer } 1 \\
(\mathrm{MBF} 4)\end{array}$ & Low & 243 & 262 & $3.75^{(\mathrm{e})}$ & $6.60^{(\mathrm{d})}$ & $12.77^{(\mathrm{f})}$ & $0.39^{(\mathrm{e})}$ & $25.10^{(\mathrm{c})}$ & $16.69^{(b)}$ & $41.78^{(\mathrm{d})}$ & $80^{(\mathrm{a})}$ \\
\hline $\begin{array}{l}\text { Matrix Based } \\
\text { Fertilizer } 3 \\
(\text { MBF5) }\end{array}$ & Low & 121 & 235 & $3.44^{(\mathrm{e})}$ & $6.07^{(\mathrm{d})}$ & $5.73^{(\mathrm{f})}$ & $0.17^{(\mathrm{e})}$ & $28.27^{(\mathrm{c})}$ & $16.41^{(b)}$ & $44.69^{(\mathrm{d})}$ & $75^{(\mathrm{a})}$ \\
\hline $\begin{array}{l}\text { Osmocote } \\
14-14-14 \\
(\mathrm{SRF})\end{array}$ & Low & 267 & 255 & $12.98^{(\mathrm{c})}$ & $11.90^{(\mathrm{bc})}$ & $173.77^{(\mathrm{c})}$ & $4.53^{(\mathrm{c})}$ & $50.23^{(\mathrm{b})}$ & $16.74^{(\mathrm{b})}$ & $66.97^{(\mathrm{bc})}$ & $60^{(\mathrm{a})}$ \\
\hline $\begin{array}{l}\text { Matrix Based } \\
\text { Fertilizer } 1 \\
(\mathrm{MBF} 4)\end{array}$ & Moderate & 486 & 524 & $3.91^{(\mathrm{e})}$ & $6.30^{(\mathrm{d})}$ & $30.44^{(\mathrm{e})}$ & $0.91^{(\mathrm{e})}$ & $30.16^{(\mathrm{c})}$ & $17.28^{(\mathrm{b})}$ & $47.44^{(\mathrm{d})}$ & $63^{(\mathrm{a})}$ \\
\hline $\begin{array}{l}\text { Matrix Based } \\
\text { Fertilizer } 3 \\
\text { (MBF5) }\end{array}$ & Moderate & 242 & 470 & $3.24^{(\mathrm{e})}$ & $5.42^{(\mathrm{d})}$ & $7.40^{(\mathrm{f})}$ & $0.24^{(\mathrm{e})}$ & $33.11^{(\mathrm{c})}$ & $17.01^{(b)}$ & $50.12^{(\mathrm{d})}$ & $73^{(\mathrm{a})}$ \\
\hline $\begin{array}{l}\text { Osmocote } \\
14-14-14 \\
\text { (SRF) }\end{array}$ & Moderate & 534 & 510 & $20.91^{(b)}$ & $17.47^{(\mathrm{b})}$ & $258.16^{(\mathrm{b})}$ & $51.75^{(\mathrm{b})}$ & $54.68^{(\mathrm{b})}$ & $16.88^{(\mathrm{b})}$ & $71.56^{(\mathrm{b})}$ & $79^{(\mathrm{a})}$ \\
\hline $\begin{array}{l}\text { Matrix Based } \\
\text { Fertilizer } 1 \\
(\text { MBF4) }\end{array}$ & High & 729 & 786 & $7.05^{(\mathrm{d})}$ & $8.20^{(\mathrm{cd})}$ & $72.81^{(\mathrm{d})}$ & $3.61^{(\mathrm{d})}$ & $38.99^{(\mathrm{c})}$ & $17.29^{(b)}$ & $56.28^{(\mathrm{cd})}$ & $75^{(\mathrm{a})}$ \\
\hline $\begin{array}{l}\text { Matrix Based } \\
\text { Fertilizer } 3 \\
(\text { MBF5) }\end{array}$ & High & 363 & 705 & $7.16^{(\mathrm{d})}$ & $5.38^{(\mathrm{d})}$ & $11.07^{(\mathrm{f})}$ & $0.86^{(\mathrm{e})}$ & $30.33^{(\mathrm{c})}$ & $16.81^{(\mathrm{b})}$ & $47.15^{(\mathrm{d})}$ & $74^{(\mathrm{a})}$ \\
\hline $\begin{array}{l}\text { Osmocote } \\
14-14-14 \\
(\mathrm{SRF})\end{array}$ & High & 801 & 765 & $27.29^{(a)}$ & $23.28^{(a)}$ & $402.68^{(\mathrm{a})}$ & $114.70^{(\mathrm{a})}$ & $69.73^{(\mathrm{a})}$ & $18.65^{(a)}$ & $88.02^{(a)}$ & $82^{(\mathrm{a})}$ \\
\hline
\end{tabular}

\footnotetext{
(a) In each column, values followed by the same letter are not significantly different as determined by the least square means test $(P \leq .05$; $n=6)$. ${ }^{\text {(b) }}$ Statistical comparisons of parameters in water are presented with regard to fertilizer $\times$ rate because interactions of fertilizer $\times$ rate $\times$ soil $\times$ week sampled, fertilizer $\times$ rate $\times$ soil, and fertilizer $\times$ rate $\times$ week sampled were not significant in the GLM model $(P \leq .05 ; n=6)$. ${ }^{(c)}$ Percent $(\%)$ of fine roots infected with arbuscular mycorrhizae.
}

treatments because GLM models showed these interactions were significant at $P \leq .05[17,18]$. Plants given the SRF fertilizer hadgreater shoot, root and total biomass than plants given the MBF4 and MBF5 fertilizers (Table 4). When fertilizers were applied at the high rate, plants receiving MBF4 had decreased shoot and total biomass by $44 \%$ and $36 \%$, respectively, compared to plants receiving SRF. Plants receiving MBF5 had decreased shoot biomass by $56 \%$ and decreased total biomass by $46 \%$ compared the plants receiving SRF. At the moderate rate plants growing in soils receiving SRF had greater shoot, root, and total biomass than all fertilizer formulations. Plants receiving MBF4 had decreased shoot and total biomass by $45 \%$ and $34 \%$, respectively, compared to plants receiving SRF. Plants receiving MBF5 had decreased shoot biomass by 39\% and decreased total biomass by $30 \%$ compared to plants receiving SRF. When fertilizers were applied at low, moderate, or high rates, the concentrations of $\mathrm{N}, \mathrm{P}$ were higher in shoot tissue than in shoot tissue of plants receiving MBF4 or MBF5. Arbuscular mycorrhazal infection in plant roots did not consistently differ among plants growing in soil receiving SRF and all MBF formulations and plants growing in soils receiving no fertilizer.

When applied at low moderate or high rates, after 126 days, SRF leachate contained a greater amount of DRP, TP, $\mathrm{NO}_{3}$, and $\mathrm{NH}_{4}$ than leachate from MBF4 and MBF5. At the low rate SRF leachate contained $71 \%$ more DRP, $45 \%$ more TP, 93\% more $\mathrm{NO}_{3}$, and 91\% more $\mathrm{NH}_{4}$ than leachate MBF4 columns. At the low rate SRF leachate contained $73 \%$ more DRP, $49 \%$ more TP, $97 \%$ more $\mathrm{NO}_{3}$, and $96 \%$ more $\mathrm{NH}_{4}$ than leachate MBF5 columns. At the moderate rate SRF leachate contained $81 \%$ more DRP, 64\% more TP, $88 \%$ more $\mathrm{NO}_{3}$, and $98 \%$ more $\mathrm{NH}_{4}$ than leachate MBF4 columns. When fertilizers were applied at the moderate 
rate SRF leachate contained $85 \%$ more DRP, 69\% more TP, 97\% more $\mathrm{NO}_{3}$, and 99\% more $\mathrm{NH}_{4}$ than leachate MBF5 columns. When fertilizers were applied at the high rate SRF leachate contained $74 \%$ more DRP, $65 \%$ more TP, $82 \%$ more $\mathrm{NO}_{3}$, and $97 \%$ more $\mathrm{NH}_{4}$ than leachate MBF4 columns. When fertilizers were applied at the high rate SRF leachate contained $74 \%$ more DRP, $77 \%$ more TP, 97\% more $\mathrm{NO}_{3}$, and $99 \%$ more $\mathrm{NH}_{4}$ than leachate MBF5 columns.

When fertilizers were applied at low, moderate, or high rates, the concentrations of $\mathrm{N}, \mathrm{P}$ were higher in shoot tissue than in shoot tissue of plants receiving MBF4 or MBF5. When fertilizers were applied at low, moderate, or high rates the concentrations of $\mathrm{K}, \mathrm{Ca}, \mathrm{Mg}, \mathrm{Zn}, \mathrm{Al}$ and $\mathrm{Na}$ in shoot tissue did not differ (data not shown). When fertilizers were applied at low rate, the concentrations of $\mathrm{N}, \mathrm{P}, \mathrm{K}, \mathrm{Ca}, \mathrm{Mg}$, $\mathrm{Mn}, \mathrm{Al}, \mathrm{Zn}$, and $\mathrm{Na}$ in shoot tissue did not differ (data not shown). When fertilizers were applied at moderate rate the concentrations of $\mathrm{N}, \mathrm{K}, \mathrm{Ca}, \mathrm{Mg}, \mathrm{Mn}, \mathrm{Al}, \mathrm{Zn}$, and $\mathrm{Na}$ in shoot tissue did not differ. When fertilizers were applied at high rate $\mathrm{P}$ concentration was higher in root tissue of plants receiving SRF than MBF4 or MBF5. When fertilizers were applied at high rate, the $\mathrm{N}$ concentration in root tissue was higher in plants receiving SRF and MBF4 than MBF5. When fertilizers were applied at low, moderate, or high rates, $\mathrm{Fe}$ concentration in root tissue was higher in plants receiving MBF5 than SRF or MBF4.

Correlations were determined using DRP, TP, $\mathrm{NH}_{4}$, and $\mathrm{NO}_{3}$ and days since fertilizers were applied to compare leaching rates among fertilizers. Correlation coefficients $\left(R^{2}\right.$ values) were variable and ranged from 0.13 to 0.32 in the DRP and TP equations (data not shown). Correlation coefficients $\left(R^{2}\right.$ values) were variable and ranged from 0.12 to 0.70 in the $\mathrm{NO}_{3}$ and $\mathrm{NH}_{4}$ equations (data not shown).

\section{Discussion}

When applied at low moderate or high rates, regardless of whether the fertilizers were pellets, banded, or broadcast, SRF leachate contained much greater amounts of $\mathrm{NO}_{3}, \mathrm{NH}_{4}$, DRP, and TP than leachate from MBF4 and MBF5. Correlations were determined using DRP, $\mathrm{TP}, \mathrm{NH}_{4}$, and $\mathrm{NO}_{3}$ and days since fertilizers were applied to compare leaching rates among fertilizers. The correlation coefficients ( $r^{2}$ values) were variable and usually low in the DRP, TP, and $\mathrm{NH}_{4}$ correlations, but generally higher in the $\mathrm{NO}_{3}$ correlations. The MBF fertilizers seem to prevent DRP, TP and $\mathrm{NH}_{4}$ leaching better than $\mathrm{NO}_{3}$ leaching. Statistical comparisons of DRP, TP, $\mathrm{NO}_{3}$, and $\mathrm{NH}_{4}$ leaching from the GLM models and mean separation and least square means tests gave similar results as the correlation equations. However, statistical comparisons of DRP, TP, $\mathrm{NO}_{3}$, and $\mathrm{NH}_{4}$ leaching from the GLM models and mean separation and least square means tests gave a higher degree of significance among means.

St. Augustine grass growing in soils receiving SRF had greater plant biomass shoot and root $\mathrm{N}$ and $\mathrm{P}$ content than all MBF formulations regardless of fertilizer form or the amount of fertilizer applied. St. Augustine grass growing in soils receiving SRF (Osmocote 14-14-14) had 33\%-49\% greater biomass than those growing in MBF formulations. Entry and Soka $[6,7]$ found similar results when Soft spring wheat, (Triticum aestivum L.) Kentucky bluegrass (Poa pratensis L.), and Kochia (Kochia scoparia L.) received (Osmocote 1414-14) these same MBF fertilizers. However, plants growing in soils receiving SRF had $15 \%-55 \%$ greater plant biomass than those growing in MBF formulations $[6,7]$. The growth rate of plants in soils receiving SRF was greater than those growing in soil receiving MBF formulations presumably because in soils receiving SRF, the nutrients were more available to the plant. The MBF formulations contained more $\mathrm{N}$ and $\mathrm{P}$ than the SRF fertilizers, but a significant amount of the nutrients were bound to the $\mathrm{Al}_{2}\left(\mathrm{SO}_{4}\right)_{3} \cdot 18 \mathrm{H}_{2} \mathrm{O}$ or $\mathrm{Fe}_{2}\left(\mathrm{SO}_{4}\right)_{3} \cdot 3 \mathrm{H}_{2} \mathrm{O}$-, starch-chitosan-lignin exchange matrix, and more slowly available to plants. A small fraction of $\mathrm{N}$ and $\mathrm{P}$ is probably immobilized in the matrix and only available to plants over months or years. Future studies need to modify the MBF fertilizer matrix to increase plant growth while reducing $\mathrm{N}$ and $\mathrm{P}$ leaching. When applied at low, moderate, or high rates $\mathrm{Fe}$ concentration in root tissue was higher in plants receiving MBF5 than SRF or MBF4 because $\mathrm{Al}$ and $\mathrm{Fe}$ are incorporated in the MBF fertilizers to reduce $\mathrm{P}$ leaching. In some crops higher plant Fe concentrations may be undesirable. Other phosphorus binding compounds such as $\mathrm{Al}_{2}\left(\mathrm{SO}_{4}\right)_{3} \cdot 18 \mathrm{H}_{2} \mathrm{O}$ could replace $\mathrm{Fe}_{2}\left(\mathrm{SO}_{4}\right)_{3} \cdot 3 \mathrm{H}_{2} \mathrm{O}$ in some MBF formulations.

Direct losses of P from fertilizer leaching or runoff usually result when fertilizer application is coincident with heavy rain events [19]. Our results imply that, even if the slow release fertilizers available on the market today were applied at rates to meet crop or turf $\mathrm{P}$ nutrition over a growing season and plants grew at their maximum potential, it would be difficult for them to take up a sufficient amount of fertilizer $\mathrm{P}$ to prevent leaching. Therefore, even if agricultural and turfgrass operators were to apply nutrients in amounts anticipated to meet plant requirements over the growing season, substantial amounts of $\mathrm{N}$ and $\mathrm{P}$ could be leached. The problem is made more severe because some turfgrass operators and homeowners often apply nutrients in quantities exceeding Plant requirements [20]. Several studies indicated that sediment bound $\mathrm{P}$ concentrations in runoffgenerally increase as soil $\mathrm{P}$ concentrations increase [21-24]. Long-term overfertilization of soils is recognized as potentially contributing to eutrophication of surface waters $[15,25]$.

Conventional SRF formulations such as single super phosphate (SSP), monoammonium phosphate (MAP), and diammonium phosphate (DAP) were developed with the goal of minimizing the production costs per unit of soluble P. The study of SSP, MAP, and DAP modification to reduce susceptibility to $\mathrm{P}$ runoff and leaching has been limited [23]. Slow-release fertilizers have been employed to reduce direct fertilizer runoff losses. Nutrient leaching from slow release fertilizers is reduced through degradation of an organic or inorganic coating around a core of inorganic fertilizer. Quin et al. [26] describe coating a DAP with a slurry of elemental sulfur which provides a short-term barrier 
to water. Field trials demonstrated an approximately $40 \%$ reduction of $\mathrm{P}$ runoff during the first runoff event after application. Nash et al. [27] conducted laboratory dissolution studies comparing SSP and a dry sulfur-coated superphosphate, in which sulfate of ammonia was the binding agent. The authors found that the water-extractable $\mathrm{P}$ was greater than the coated superphosphate fertilizer treatments $(6.6 \%)$ compared to $4.8 \%$ from superphosphate treatments. The rapid dissolution of the $\mathrm{S}$-coated superphosphate resulted in the rapid solubilization of the sulfate of ammonia in the extraction procedure and with it removal of the sulfur coat and protection against $\mathrm{P}$ dissolution in the granules [24].

Commercial slow release fertilizers can be classified into two basic groups: low solubility and polymer-coated water soluble fertilizers [28]. The polymer-coated slow release fertilizers are water soluble and can exhibit consistent nutrient release rates. However average soil temperature and moisture need to be known. The fertilizers are characterized by one or more polymeric resins surrounding the fertilizer. The duration of nutrient release is controlled by the porosity of the resin coating. A more porous coating results in quicker release. When polymer-coated slow release fertilizers are applied to the soil, the water in the soil enters the fertilizer granule through micropores dissolving the nutrients. Nutrients are then steadily released through the same pores. The rates of nutrient release of polymer-coated slow release fertilizers are influenced by soil temperature; the higher the soil temperature, the greater the release rate [28]. Release rate is hypothesized to not be significantly influenced by microbiological decomposition, soil moisture, soil type, or $\mathrm{pH}$. However, all polymers eventually degrade in soil [29-32] and the degradation rate influences nutrient release from the polymer.

The MBF formulations in our study cover a range of common inorganic nutrient compounds combined with $\mathrm{Al}_{2}\left(\mathrm{SO}_{4}\right)_{3} \cdot 18 \mathrm{H}_{2} \mathrm{O}$ and/or $\mathrm{Fe}_{2}\left(\mathrm{SO}_{4}\right)_{3} \cdot 3 \mathrm{H}_{2} \mathrm{O}$ and the high ionic exchange compounds, starch, chitosan, and lignin. These formulations allow nutrients to bind with the $\mathrm{Al}_{2}\left(\mathrm{SO}_{4}\right)_{3} \cdot 18 \mathrm{H}_{2} \mathrm{O}$ and/or $\mathrm{Fe}_{2}\left(\mathrm{SO}_{4}\right)_{3} \cdot 3 \mathrm{H}_{2} \mathrm{O}$-lignin-chitosan matrix substantially reducing leaching. Once $\mathrm{N}$ and $\mathrm{P}$ are bound to the $\mathrm{Al}\left(\mathrm{SO}_{4}\right)_{3} \cdot 18 \mathrm{H}_{2} \mathrm{O}$ and/or $\mathrm{Fe}_{2}\left(\mathrm{SO}_{4}\right)_{3} \cdot 3 \mathrm{H}_{2} \mathrm{O}$ lignin-chitosan matrix, they become slowly available to plants over one or more growing seasons. After the starch-chitosan-lignin matrix with $\mathrm{Al}_{2}\left(\mathrm{SO}_{4}\right)_{3} \cdot 18 \mathrm{H}_{2} \mathrm{O}$ and/or $\mathrm{Fe}_{2}\left(\mathrm{SO}_{4}\right)_{3} \cdot 3 \mathrm{H}_{2} \mathrm{O}$ is applied to soil, the soil microorganisms degrade the starch in the matrix comparatively rapidly creating some ionic exchange sites. The chitosan degrades less rapidly than starch but more rapidly than lignin and is expected to retain most of its ionic exchange sites for about a year in most soil environments. The lignin component in the matrix degrades more slowly than starch or chitosan and retains its ionic exchange sites for more than a year in most soil environments. Nutrient availability and leaching is expected to be controlled to a large degree by varying the relative amounts of starch-chitosan-lignin matrix with $\mathrm{Al}_{2}\left(\mathrm{SO}_{4}\right)_{3} \cdot 18 \mathrm{H}_{2} \mathrm{O}$ and/or $\mathrm{Fe}_{2}\left(\mathrm{SO}_{4}\right)_{3} \cdot 3 \mathrm{H}_{2} \mathrm{O}$ in the mixture. $\mathrm{MBF}$ application rates must be based on the amount of $\mathrm{N}$ and $\mathrm{P}$ released to meet plant growth. Therefore their application rates will necessarily not be comparable to existing conventional or slow release fertilizers which because of more rapid availability, but also more leaching, are applied to soil based on the amount of nutrient in $\mathrm{kg}$ fertilizer $\mathrm{ha}^{-1}$ applied. Conventional rate calibration research for MBF fertilizers in field settings has not yet been performed.

Mycorrhizal colonization in plant roots did not differ among the unfertilized controls, SRF, MBF4, and MBF5 formulations. Entry and Soka [6, 7] found similar results. Mycorrhizal colonization was assessed at the termination of the experiment when roots were growing throughout the soil. Glomus interadicies is an arbuscular mycorrhizal fungi species that will form associations with a broad range of host plants in soils containing high concentrations of nitrogen and phosphorus. Glomus interadicies was added to the matrix to enhance plant uptake of $\mathrm{N}$ and $\mathrm{P}$. In most soils arbuscular mycorrhizal spores are probably not necessary in the MBF formulations.

The impact of, MBF fertilizers to reduce $\mathrm{N}$ and $\mathrm{P}$ leaching in the field may not be less readily apparent in agricultural soils with loamy to clayey textures. Similarly agricultural production fields with long histories of high $\mathrm{N}$ or $\mathrm{P}$ rate applications would be less likely to exhibit changes in nutrient response or leaching results initially with conversion to MBFs because of nutrient enrichment in the soil [33-37]. Fertilizer $\mathrm{N}$ and $\mathrm{P}$ will also have become incorporated into organic matter complexes which will result in these nutrients being released as organic matter is decomposed [33, 34, 38]. The efficacy of MBF fertilizers to reduce $\mathrm{N}$ and $\mathrm{P}$ input to surface and ground water should be more apparent on highly leached sandy soils than soils containing high concentrations of silt, clay, or organic matter.

\section{Conclusions}

These new fertilizer formulations do not depend on organic or inorganic coatings to reduce $\mathrm{N}$ and $\mathrm{P}$ leaching and with further testing and development could be more effective than commercial fertilizers. The MBFs must be formulated to equal or improve plant growth relative to commercial fertilizers. Although further greenhouse and field testing are necessary, results of this initial investigation are promising. Cost estimates of these MBF fertilizers have been calculated to be $\$ 0.03-0.08 \mathrm{~kg}^{-1}$ above the cost of conventional fertilizers. One of the main goals of future research should be to reduce the cost of $\mathrm{MBF}$ production. $\mathrm{MBF}$ initially may be economically feasible for use by homeowners on their lawns, turf grass operators such as golf course managers, nursery managers, and growers of high value agricultural crops. The MBF formulations could prove important in soils whose water drains into nutrient-affected watersheds such as Chesapeake Bay, Florida Everglades, and rivers flowing into the Great Lakes.

As nutrients are applied to a soil they can accumulate to the maximum retention capacity of the soil, which is controlled by soil physical and chemical properties, the resident biota, and the rate of nutrient uptake by vegetation. Excessive application of any fertilizer eventually will load soil beyond its maximum retention capacity. Nutrients added to the soil above that limit via any mode of application 
eventually can be released to water flowing over and/or through the soil. Improved technology cannot substitute fully for adhering to sound land management practices. In the long term $\mathrm{N}$ and $\mathrm{P}$ contamination of water can be prevented only by applying nutrients in quantities relative to the inherent capacity of the soil to retain nutrients and the quantities removed via harvest. However, new MBF formulations that release nutrients at a rate comparable to plant uptake can help reduce nutrient leaching and ultimately eutrophication.

\section{Acknowledgments}

The authors thank Sheryl Verwey for assistance with greenhouse operations and nutrient analysis and James Forester for assistance with graphic design.

\section{References}

[1] B. J. Bush and N. R. Austin, "Timing of phosphorus fertilizer application within an irrigation cycle for perennial pasture," Journal of Environmental Quality, vol. 30, no. 3, pp. 939-946, 2001.

[2] D. F. Boesch, R. B. Brinsfield, and R. E. Magnien, "Chesapeake Bay eutrophication: scientific understanding, ecosystem restoration, and challenges for agriculture," Journal of Environmental Quality, vol. 30, no. 2, pp. 303-320, 2001.

[3] T. C. Daniel, A. N. Sharpley, and J. L. Lemunyon, "Agricultural phosphorus and eutrophication: a symposium overview," Journal of Environmental Quality, vol. 27, no. 2, pp. 251-257, 1998.

[4] S. B. Bricker, C. G. Clement, D. E. Pirhalla, S. P. Orlando, and D. R. G. Farrow, National Etuarine Eutrophication Assessment: Effects of Nutrient Enrichment in the Nations Estuaries, NOAA, National Ocean Service, Special Projects Office and the Centers for Coastal Ocean Science, Silver Spring, Md, USA, 1999.

[5] A. R. Zimmerman and E. A. Canuel, "A geochemical record of eutrophication and anoxia in Chesapeake Bay sediments: anthropogenic influence on organic matter composition," Marine Chemistry, vol. 69, no. 1-2, pp. 117-137, 2000.

[6] J. A. Entry and R. E. Sojka, "Matrix based fertilizes with arbuscular mycorrhizae reduce nitrogen and phosphorus leaching in greenhouse column studies," Water, Air and Soil Pollution, vol. 180, pp. 283-292, 2007.

[7] J. A. Entry and R. E. Sojka, "Matrix based fertilizes reduce nitrogen and phosphorus leaching in three soils," Journal of Environmental Management, vol. 87, no. 3, pp. 364-372, 2008.

[8] R. A. Collett, Soil Survey of Ada County, U.S. Department of Agriculture, Natural Resources Conservation Service, U.S. Government Printing Office, Washington, DC, USA, 1982.

[9] R. E. Sojka, J. A. Entry, and J. J. Fuhrmann, "The influence of high application rates of polyacrylamide on microbial metabolic potential in an agricultural soil," Applied Soil Ecology, vol. 32, no. 2, pp. 243-252, 2006.

[10] J. A. Entry, R. E. Sojka, and G. E. Shewmaker, "Management of irrigated agriculture to increase organic carbon storage in soils," Soil Science Society of America Journal, vol. 66, no. 6, pp. 1957-1964, 2002.

[11] R. E. Koske and J. N. Gemma, "A modified staining procedure for staining roots to detect V-A mycorrhizae," Mycological Research, vol. 92, pp. 486-488, 1989.
[12] T. P. McGonigle, M. H. Miller, D. G. Evans, G. L. Fairchild, and J. A. Swan, "A new method which gives an objective measure of colonization of roots by vesicular-arbuscular mycorrhizal fungi," New Phytologist, vol. 115, no. 3, pp. 495-501, 1990.

[13] APHA, Standard Methods for the Examination of Water and Wastewater, American Public Health Association, American Water Works Association, and Water Environment Federation, Washington, DC, USA, 1998.

[14] H. M. Bremmner, "Nitrogen-total," in Methods of Soil Analysis. Part 3. Chemical Methods, D. L. Sparks, Ed., pp. 1085-1122, American Society of Agronomy, Madison, Wis, USA, 1996.

[15] J. T. Sims, "Comparison of Mehlich 1 and Mehlich 3 extractants for $\mathrm{P}, \mathrm{K}, \mathrm{Ca}, \mathrm{Mg}, \mathrm{Mn}, \mathrm{Cu}$ and $\mathrm{Zn}$ in Atlantic coastal plain soils," Communications in Soil Science \& Plant Analysis, vol. 20, no. 17-18, pp. 1707-1726, 1989.

[16] W. G. Snedecor and W. G. Cochran, Statistical Methods, Iowa State University Press, Ames, Iowa, USA, 1994.

[17] SAS Institute Inc., SAS User's Guide: Statistics-Version 8.0 Edition, Statistical Analysis System (SAS) Institute Inc., Cary, NC, USA, 2001.

[18] R. E. Kirk, Experimental Design: Procedures for the Behavioral Sciences, Brooks Cole, Belmont, Calif, USA, 2nd edition, 1995.

[19] P. M. Haygarth and S. C. Jarvis, "Transfer of phosphorus from agricultural soils," Advances in Agronomy, vol. 66, pp. 195-249, 1999.

[20] M. R. Hart, B. F. Quin, and M. L. Nguyen, "Phosphorus runoff from agricultural land and direct fertilizer effects," Journal of Environmental Quality, vol. 33, no. 6, pp. 1954-1972, 2004.

[21] A. N. Sharpley, B. H. Foy, and P. J. A. Withers, "Practical and innovative measures for the control of agricultural phosphorus losses to water: an overview," Journal of Environmental Quality, vol. 29, no. 1, pp. 1-9, 2000.

[22] A. N. Sharpley, T. C. Daniel, and D. R. Edwards, "Phosphorus movement in the landscape," Journal of Production Agriculture, vol. 6, pp. 492-500, 1993.

[23] D. H. Pote, T. C. Daniel, D. J. Nichols, et al., "Relationship between phosphorus levels in three ultisols and phosphorus concentrations in runoff," Journal of Environmental Quality, vol. 28, no. 1, pp. 170-175, 1999.

[24] F. R. Cox and S. E. Hendricks, "Soil test phosphorus and clay content effects on runoff water quality," Journal of Environmental Quality, vol. 29, no. 5, pp. 1582-1586, 2000.

[25] E. Frossard, L. M. Condron, A. Oberson, S. Sinaj, and J. C. Fardeau, "Processes governing phosphorus availability in temperate soils," Journal of Environmental Quality, vol. 29, no. 1, pp. 15-23, 2000.

[26] B. F. Quin, A. Braithwaite, L. Nguyen, J. Blennerhassett, and C. J. Watson, "The modification of commodity $\mathrm{P}$ and $\mathrm{N}$ fertilisers to reduce nutrient loss to the environment," in Tools for Nutrient and Pollutant Management: Applications to Agriculture and Environmental Quality, L. D. Currie and J. A. Hanly, Eds., pp. 115-121, Occasional Rep. 17. Fertilizer and Lime Research Centre, Massey University, Palmerston North, New Zealand, 2003.

[27] D. Nash, M. Hannah, L. Clemow, D. Halliwell, B. Webb, and D. Chapman, "A laboratory study of phosphorus mobilisation from commercial fertilisers," Australian Journal of Soil Research, vol. 41, no. 6, pp. 1201-1212, 2003.

[28] A. D. Blaylock, J. Kaufmann, and R. D. Dowbenko, "Nitrogen fertilizers technologies," Western Nutrient Management, vol. 6, pp. 8-13, 2005. 
[29] A. A. Basfar, A. Idriss, K. M. Ali, and S. M. Mofti, "UV stability and radiation-crosslinking of linear low density polyethylene and low density polyethylene for greenhouse applications," Polymer Degradation and Stability, vol. 82, no. 2, pp. 229-234, 2003.

[30] S. Bonhomme, A. Cuer, A.-M. Delort, J. Lemaire, M. Sancelme, and G. Scott, "Environmental biodegradation of polyethylene," Polymer Degradation and Stability, vol. 81, no. 3, pp. 441-452, 2003.

[31] R. G. Lehmann, J. R. Miller, and G. E. Kozerski, "Degradation of silicone polymer in a field soil under natural conditions," Chemosphere, vol. 41, no. 5, pp. 743-749, 2000.

[32] R. G. Lehmann, J. R. Miller, S. Xu, U. B. Singh, and C. F. Reece, "Degradation of silicone polymer at different soil moistures," Environmental Science and Technology, vol. 32, no. 9, pp. 12601264, 1998.

[33] E. M. D’Angelo, "Phosphorus sorption capacity and exchange by soils from mitigated and late successional bottomland forest wetlands," Wetlands, vol. 25, no. 2, pp. 297-305, 2005.

[34] R. W. McDowell, L. M. Condron, I. Stewart, and V. Cave, "Chemical nature and diversity of phosphorus in New Zealand pasture soils using ${ }^{31} \mathrm{P}$ nuclear magnetic resonance spectroscopy and sequential fractionation," Nutrient Cycling in Agroecosystems, vol. 72, no. 3, pp. 241-254, 2005.

[35] J. A. Bird, C. van Kessel, and W. R. Horwath, "Stabilization of ${ }^{13} \mathrm{C}$-carbon and immobilization of ${ }^{15} \mathrm{~N}$-nitrogen from rice straw in humic fractions," Soil Science Society of America Journal, vol. 67, no. 3, pp. 806-816, 2003.

[36] J. A. Bird, C. van Kessel, and W. R. Horwath, "Nitrogen dynamics in humic fractions under alternative straw management in temperate rice," Soil Science Society of America Journal, vol. 66, no. 2, pp. 478-488, 2002.

[37] O. C. Devêvre and W. R. Horwáth, "Stabilization of fertilizer nitrogen-15 into humic substances in aerobic vs. waterlogged soil following straw incorporation," Soil Science Society of America Journal, vol. 65, no. 2, pp. 499-510, 2001.

[38] J. A. Entry and W. H. Emmingham, "Influence of forest age on nutrient availability and storage in coniferous soils of the Oregon Coast Range," Canadian Journal of Forest Research, vol. 25, no. 1, pp. 114-120, 1995. 

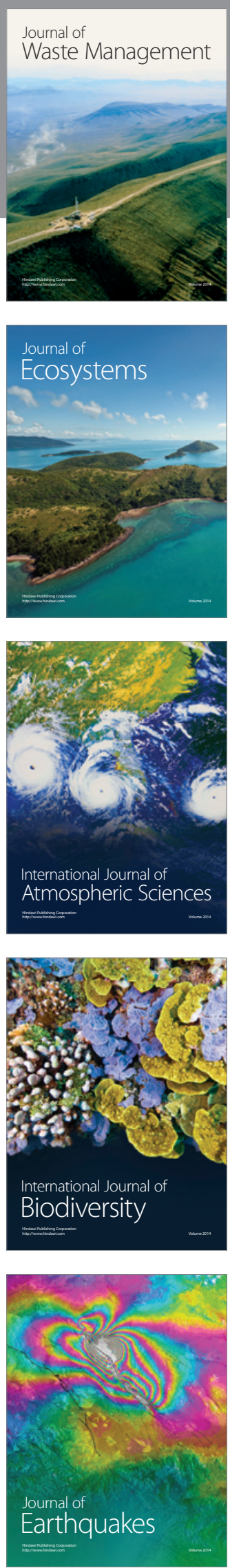
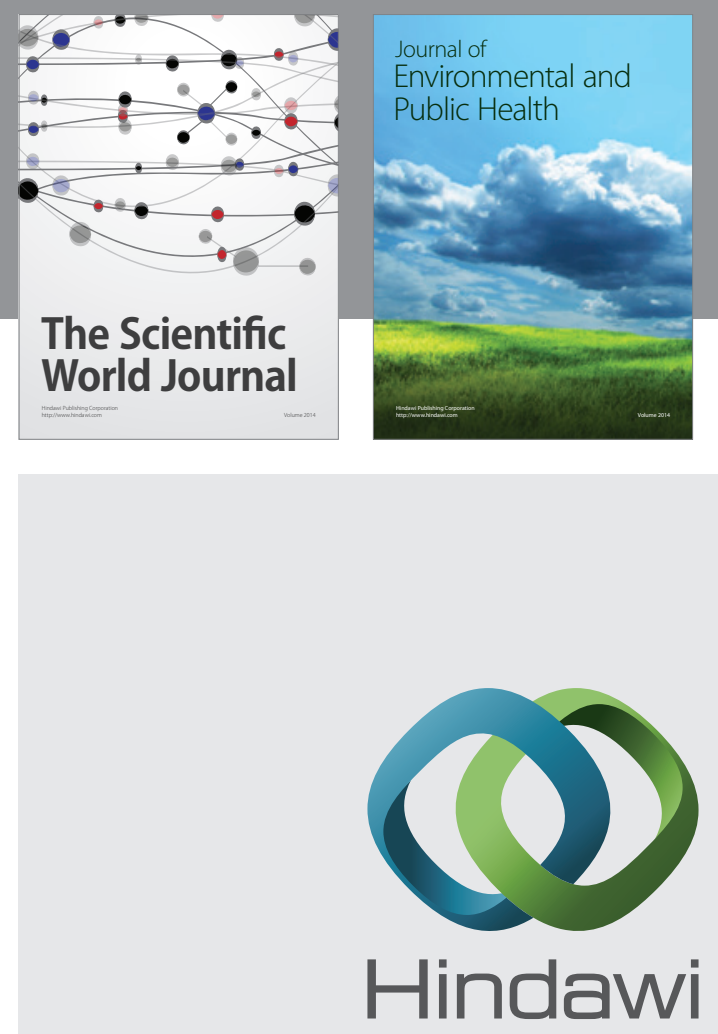

Submit your manuscripts at

http://www.hindawi.com
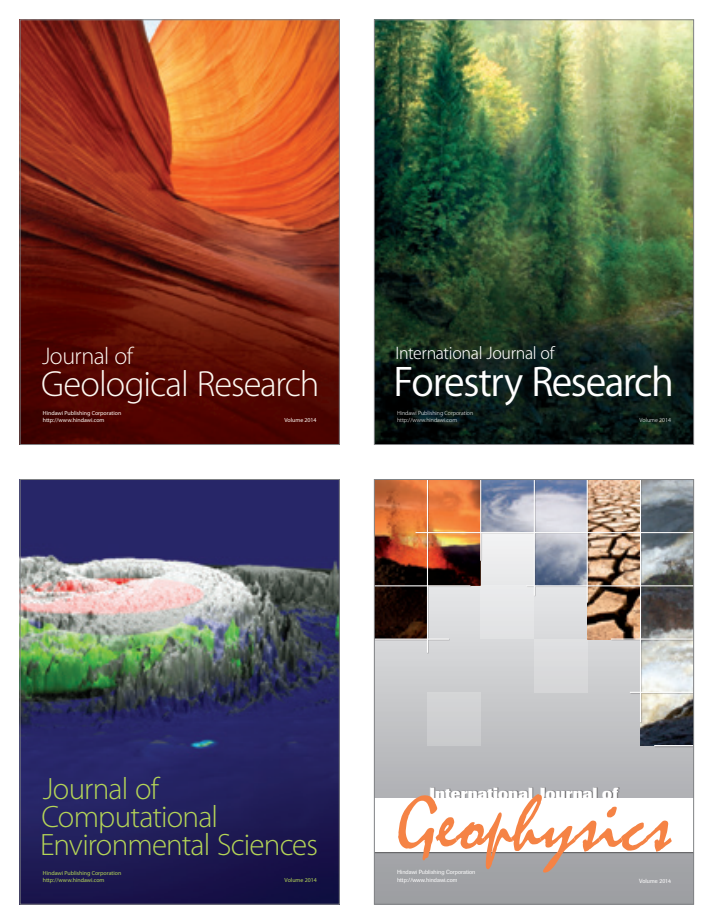
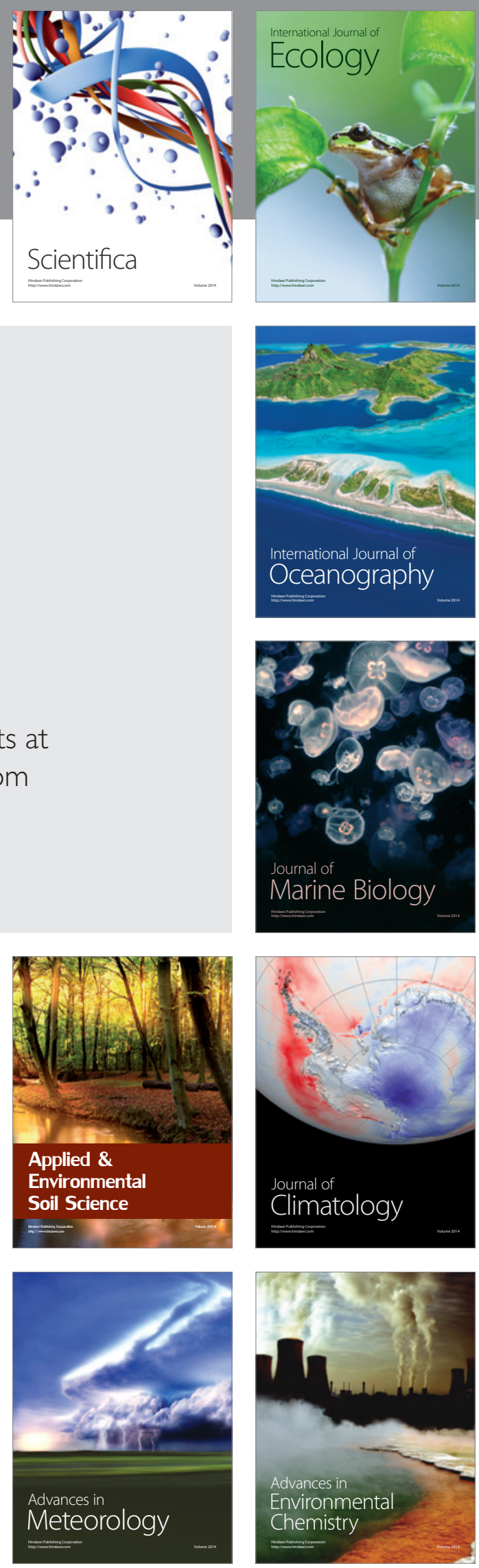